\title{
Reproductive Biology of Gerres Oyena (Pisces: Gerreidae) Along the Bagamoyo Coast, Tanzania
}

\author{
H.A. Lamtane ${ }^{1 *}$, H.B. Pratap ${ }^{2}$ and S.M.G. Ndaro ${ }^{2}$ \\ ${ }^{1}$ National Environment Management Council, P. O. Box 63154, Dar es Salaam, Tanzania; ${ }^{2}$ Department of \\ Zoology and Marine Biology, University of Dar es Salaam, P. O. Box 35064, Dar es Salaam, Tanzania; \\ *Department of Animal Science and Production, Sokoine University of Agriculture, P.O. Box 3004 Morogoro, \\ Tanzania
}

Key words: Fecundity, Gerres oyena, Gerreidae, spawning

\begin{abstract}
The reproductive biology of Gerres oyena (Forskal, 1775) (Gerreidae) along the Bagamoyo coast was studied from January to December 1999 using samples from monthly commercial catches. Size at first maturity was 12.8 and $13.9 \mathrm{~cm}$ TL for males and females respectively. The sex ratio was found to be $0.98: 1$ (m:f) and was not significantly different from 1:1. G. oyena spawns throughout the year with two peaks: one in March and the other between October and December, which coincide with the northeast monsoon. Ova-diameter frequency distributions indicated that $G$. oyena is a multiple spawner. They may spawn in three successive batches within the same prolonged spawning season. On an average, the numbers of mature ova produced were 148,138 per fish. For management purposes, a focus should be on the size of maturation relative to length-body depth or capture size. This would reduce harvesting of prereproductive individuals.
\end{abstract}

\section{INTRODUCTION}

Members of the family Gerreidae (also known as mojarras, silver-biddies or purse mouths) inhabit warm seas, are marine and estuarine, although they occasionally occur in freshwater (Cyrus \& Blaber, 1982; Blaber et al., 1995; Ndaro \& Ólafsson, 1995). The reproductive biology of the Gerreidae has been studied by Rao (1970), Kurup \& Samuel (1991) in Indian waters; Austin (1971), Etchevers (1978) in South America and Albaret \& Desfossez (1988), Cyrus \& Blaber (1984) in Africa. Many tropical and subtropical fish species have been found to retain a protracted spawning period (Johannes, 1978). Multiple spawning over a protracted period or even a full year is associated typically with less seasonal environments, smaller body size and relatively smaller ovary size (Burt et al., 1988).
Gerres oyena is common in the inshore waters of Tanzania, but there is no detailed information on its biology. The Gerres oyena fishery is important in Bagamoyo coastal waters and the fish is esteemed as food, with the major portion of the landings consumed locally (Lamtane, 2001). This study was undertaken to ascertain spawning periodicity, spawning season, minimum size at first maturity, fecundity and sex ratio from fish caught at Bagamoyo.

\section{MATERIALS AND METHODS}

Specimens of Gerres oyena, caught be beach seining, were collected monthly, between January and December 1999, from two fishing landing stations along the Bagamoyo coast (Fig. 1). Their maturity stage was estimated by visual inspection of fresh gonads. A five-point scale based on the 


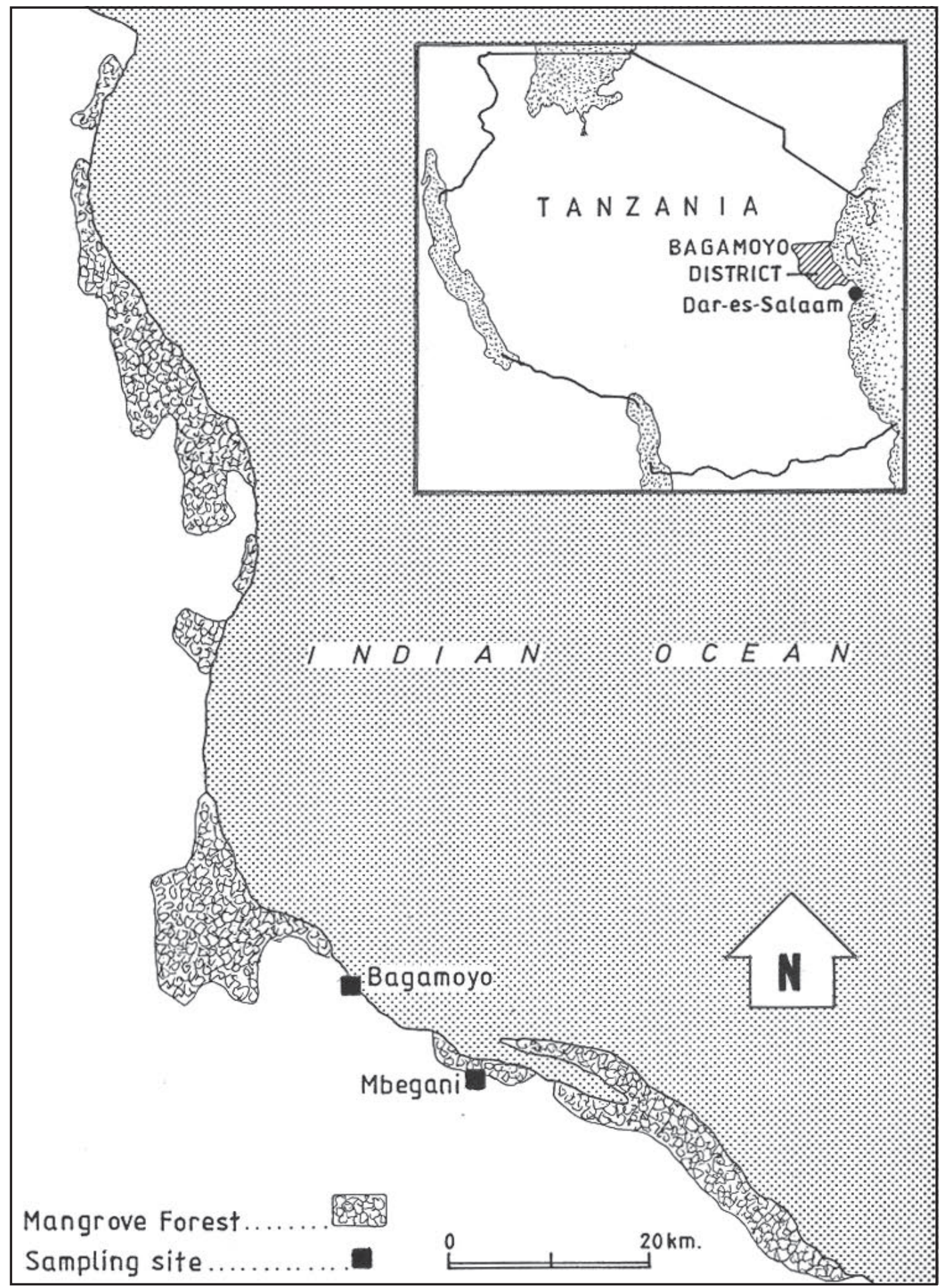

Fig. 1. A map of Bagamoyo coast showing sampling sites 
colour, shape, size and microscopic structure of the gonads, as suggested by Nikolsky (1963), was used to classify maturity stage. The gonadosomatic index was estimated for each fish by expressing the gonad weight $(\mathrm{g})$, as a percentage of the total bodyweight

(G) using the formula:

$$
I_{G}=\frac{g}{G} \times 100
$$

The frequency of spawning was determined by measuring the diameter of intraovarian eggs. Fecundity was enumerated by the volumetric subsample method as described by Bagenal \& Braum (1978) and Macer (1974).

\section{RESULTS}

A total of 1,328 specimens were sexed and 656 fish were found to be males giving a sex ratio of $0.98: 1$ $\left(\chi^{2}=0.169 ; \mathrm{P}=0.6806 ; \mathrm{df}=1\right)$. The size at which $50 \%$ of the fish are mature was taken as the size at which fish reach maturity for the first time. The percentage of sexually mature males in 11.1-13.0 $\mathrm{cm}$ size class is significantly greater than that of females $(t=12.029, d f=190, P<0.0001)$. The $L_{50}$ for length at first maturity was $12.8 \mathrm{~cm}$ and $13.9 \mathrm{~cm}$ for males and females respectively (Fig. 2). the females. This corresponds to the period of low occurrence of mature and ripe fish (Figs. 3a $\&$ b). Two reproductive peaks were observed, one in March, and the second between October and December indicating the intense gonadal activity during this period and confirmed that the major spawning season of this species was from October to December.

Fig. 5 shows frequencies of ova diameter of the maturity stage IV. In this stage three modes are marked, the mode ' $a$ ' has grown to 0.47 and mode ' $b$ ' has attained $0.29 \mathrm{~mm}$ and third mode 'c' at $0.11 \mathrm{~mm}$ is discernible. Modes at ' $a$ ' and 'b' ensure progressive development of ova which ultimately take part in the spawning activity. The ova at mode ' $a$ ' are larger than those of ' $b$ ' and 'c' and two batches of ova are not likely to be shed simultaneously. They are shed in batches one after another with an interval of time. The multiplicity of modes in the mature ovary of G. oyena denotes its repeated spawning. Fecundity was studied in 56 fish with ripe gonads from October to Deecember. Size of fish examined range from 13.2 to $20.1 \mathrm{~cm}$ TL and the number of ripe ova per fish (stage IV) varied from 22,600 to 367,200 .

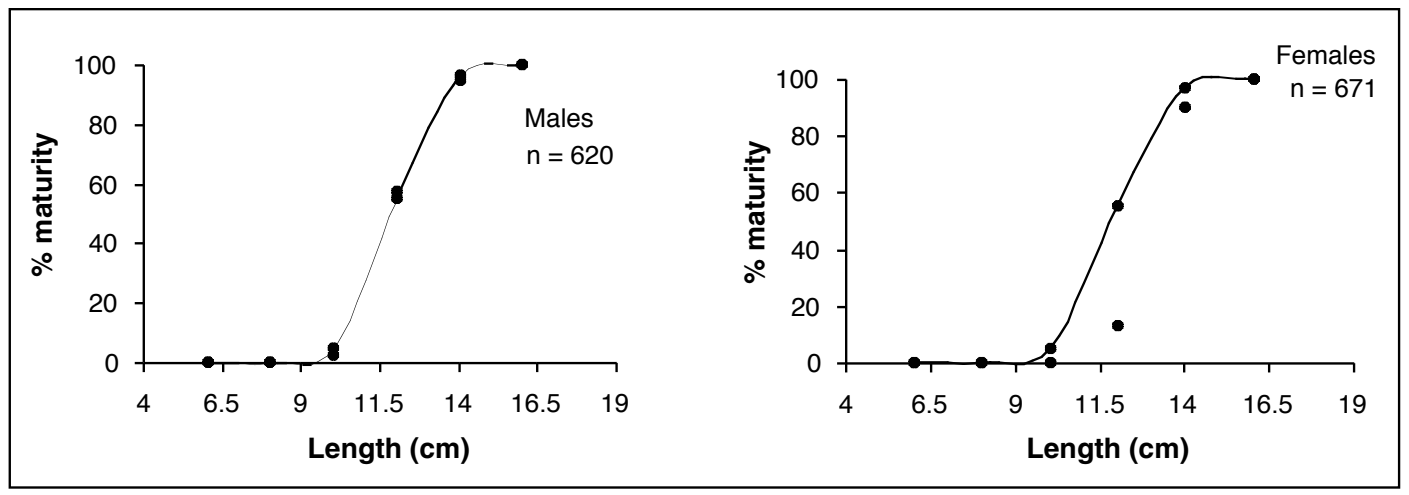

Fig. 2. Size at first maturity of females and males of $G$. oyena

Figs. $3 \mathrm{a}$ and $\mathrm{b}$ show that both males and females spawn throughout the year as indicated by the presence of mature and ripe gonads throughout the sampling period. The seasonal changes in mean gonad weight are shown in Fig. 4. The lowest value of mean $\mathrm{I}_{\mathrm{G}}$ occurs in January and May for males and in January and February for

\section{DISCUSSION}

The observed sex ratio in the fishery could be due to gear selectivity, sexual differences in growth rate, partial segregation of mature fish, or to behavioural differences between the two sexes during spawning period (Etchervers, 1978; DeMartin \& Fountain, 


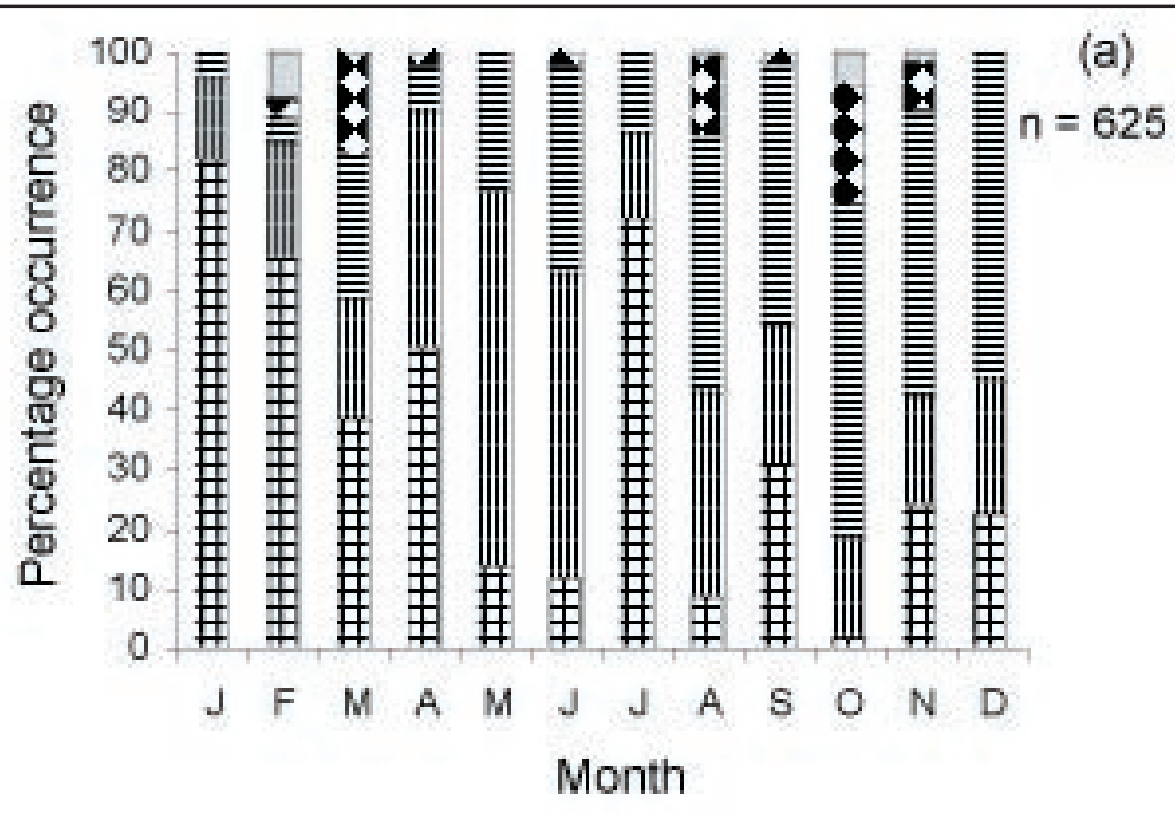

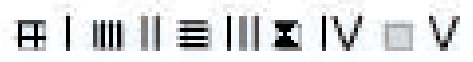

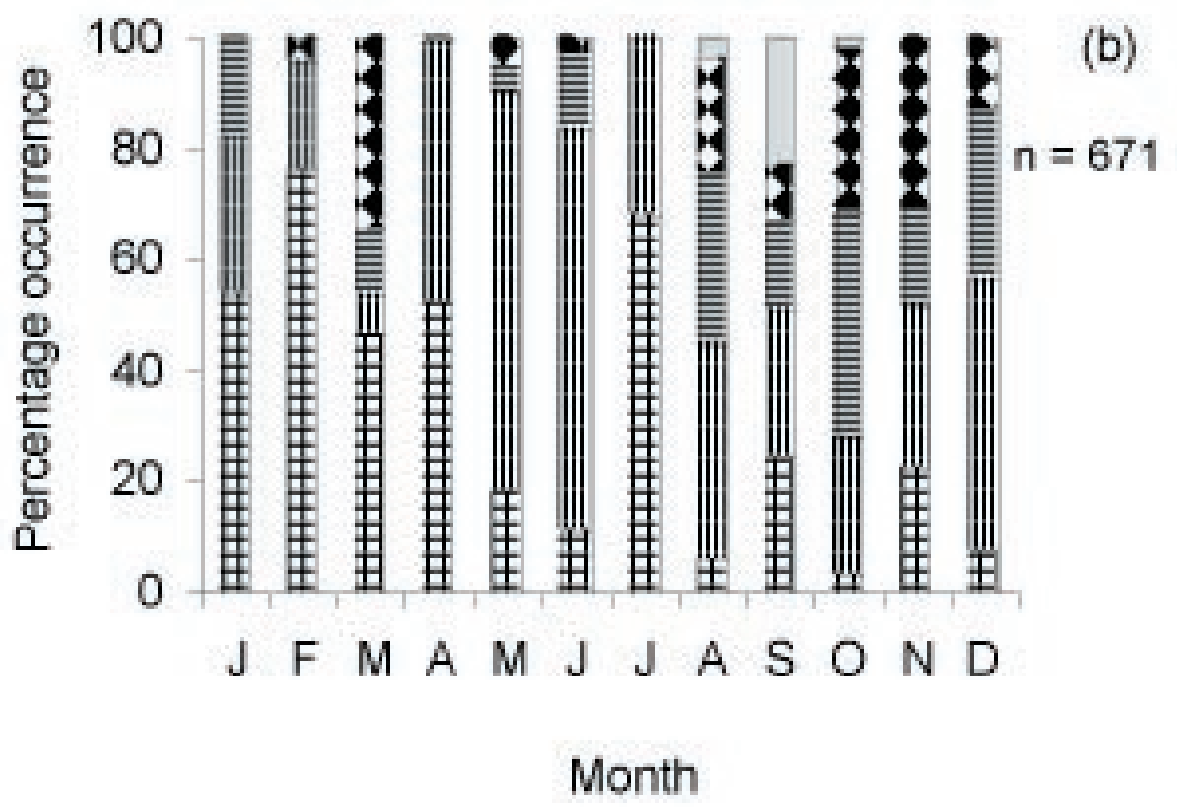

\# | $|\mathrm{II} \equiv \equiv||\mathbf{x}| \mathrm{V} \square \mathrm{V}$ 


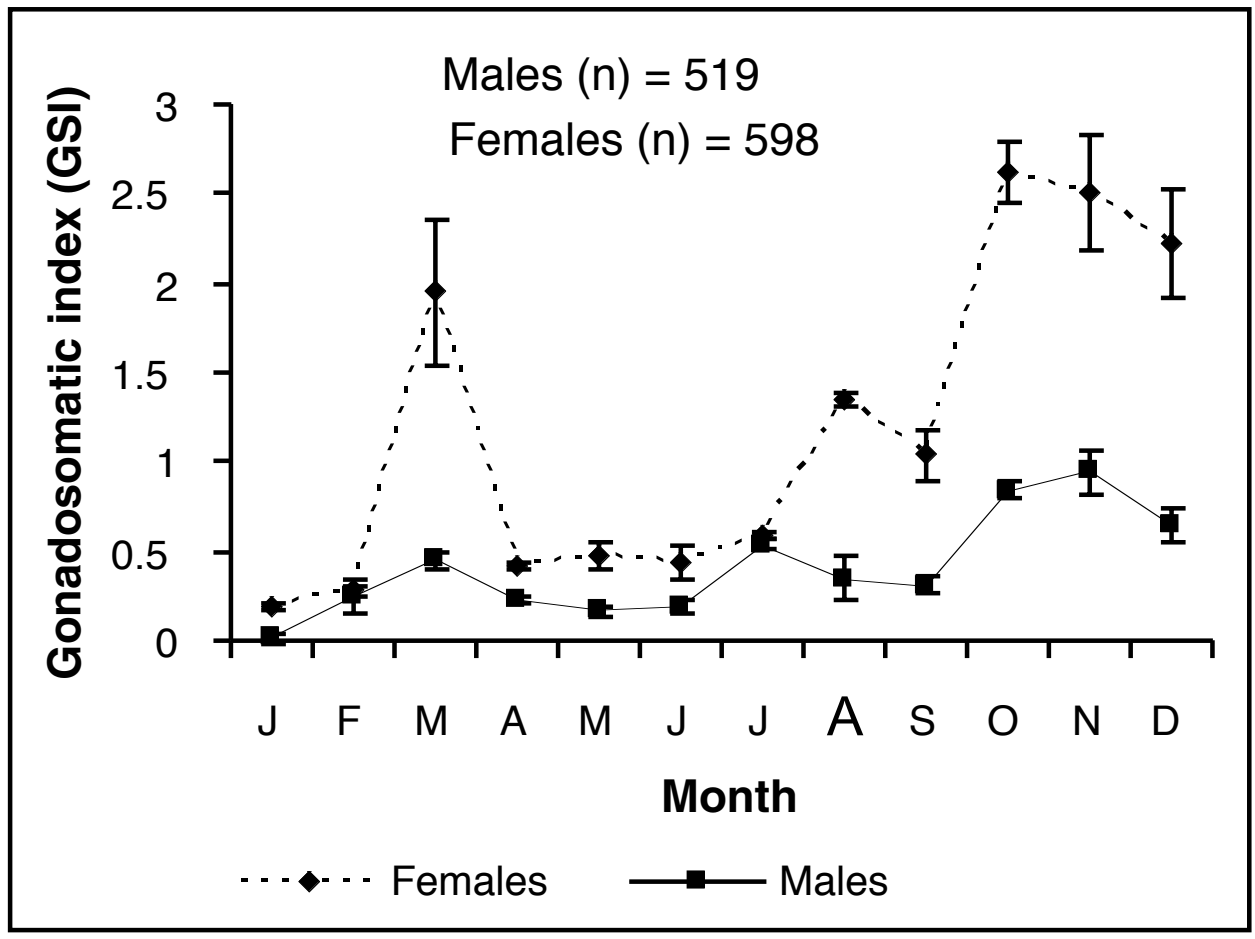

Fig. 4. Monthly variations of Gonadosomatic index $\left(I_{G}\right)$ in males and females of $G$. oyena. Vertical bars show \pm S.E.M

1981; Lowerre-Barbieri et al., 1996). In this study, male G. oyena attained sexual maturity at a smaller size than females. Similar observations and conclusions have been made by Patnaik (1971) on G.s setifer, by Etchevers (1978) on Diapterus rhombeus, by Albaret \& Desfossez (1988) on G. nigri, by Kurup \& Samuel (1991) on G. filamentosus and Sarre et al (1997) on Parequula. melbournensis. A variable body size at first sexual maturity is a common feature of serial spawners and fishes in general (DeMartin \& Fountain, 1981). For fisheries management a focus could be on the size of maturation relative to capture size so as to reduce harvesting of pre-reproductive individuals and relative to recruitment size to determine the rate at which individuals enter the reproductive population.

Gerres oyena breeds throughout the year with two peaks, one in March and the other between October and December (Figs.3 and 4). These spawning peaks coincide with the northeast monsoon (NE), which starts from October to March. Observed peaks of spawning during this season concur with most of the findings on reproduction in different fish from East African coastal waters (Talbot 1960; Merret 1971; Okera 1974; Kamukuru \& Mgaya, 2004). During the NE monsoon there a larger algal biomass and a high diversity of phytoplankton (Bryceson, 1982), and the greatest abundance of zooplankton (Kimaro, 1986).

Gerresoyena has asychronous ovary development (i.e. oocytes at all stages of development are present). Most species with asynchronous oocytic development have protracted spawning seasons with multiple spawning (West, 1990). The multiple modes (Fig. 5) in the mature ovary provide strong circumstantial evidence that G. oyena are multiple spawners. Multiple spawning increases the number of eggs that can be produced in a year (Burt et al., 1988). This reduces vulnerability to fishing and time of maturity (Lowerre-Barbieri et al., 1998), spreads the risk of predation on eggs and larvae over an extended period (Lambert \& Ware, 1984) and acts as a buffer against adverse fluctuations in the amount of food available to the larvae.

The fecundity of G. oyena is relatively higher than other Gerres species. The fecundity of Gerres setifer ranges from 17,293 to 161,505 eggs with 


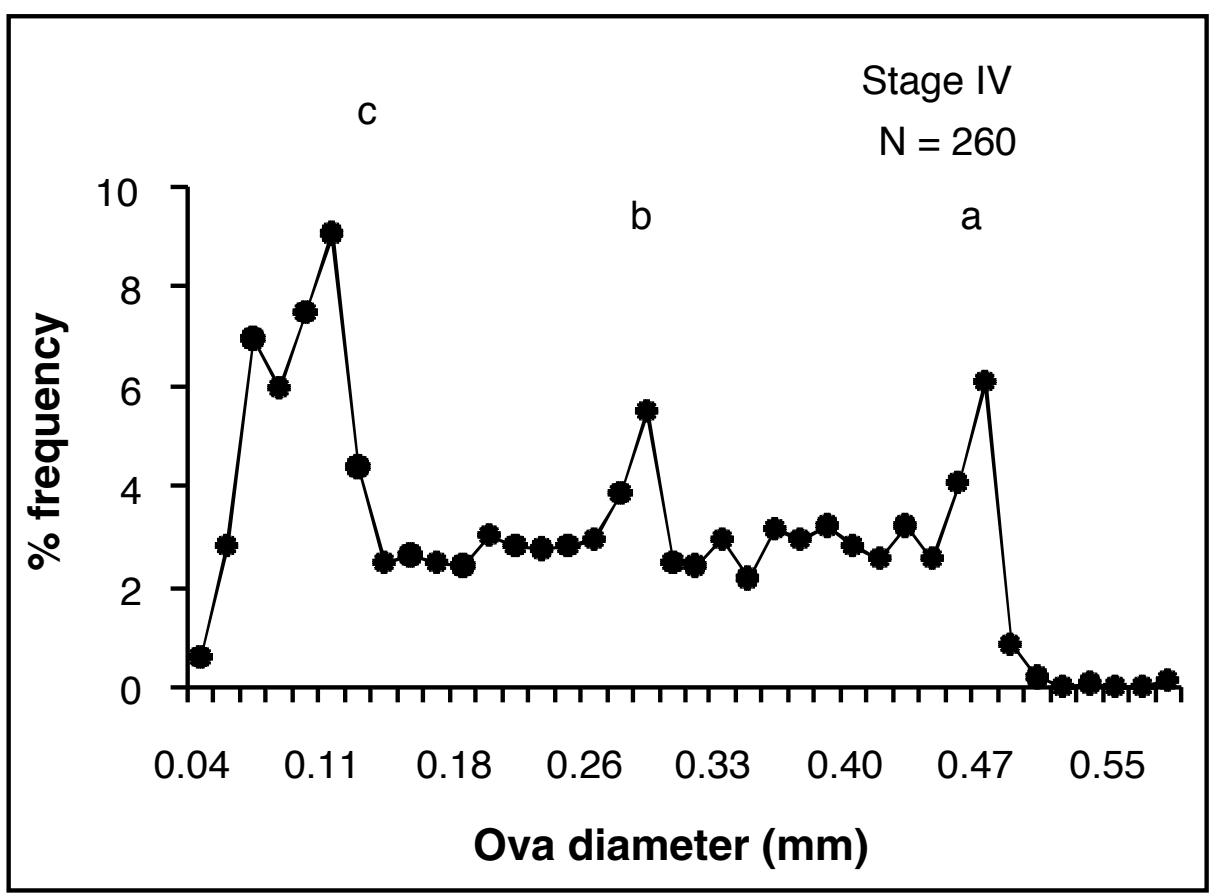

Fig. 5. Frequency distribution of ova diameter of $G$. oyena sampled between October-December

size range 88-193 mm TL (Patnaik, 1971) and $G$. filamentosus from 64,278 to 387,576 with size range 100-148 mm SL (Kurup \& Samuel, 1991). This difference may be attributed to differences in habitat and environmental conditions. In conclusion, selecting mesh sizes slightly higher than length at first maturity will allows the fish to reproduce at least once before being recruited to the fishery.

Acknowledgement-We are grateful to the Swedish Agency for Research and Economic Co-operation with Developing Countries (SAREC) for the generous financial support, which made this study possible.

\section{REFERENCES}

Albaret, J.J. and Desfossez, P. (1988). Biology and ecology of Gerreidae (Pisces, Teleostei) in the Ebrié Lagoon (Ivory Coast). Review of Hydrobiologia Tropical 21: 71-88.

Austin, H.M. (1971). Some aspects of the biology of the Rhomboid Mojarra Diapterus rhombeus in Puerto Rico. Bulletin of Marine Science 21: 886-903.

Bagenal, T.B. and Braum, E. (1978). Eggs and early life history. In: T. Bagenal (ed.), Methods for
Assessment of Fish Production in Freshwaters $3^{\text {rd }}$ edition. IBP Handbook No. 3. Blackwell Scientific publications. Oxford London Edinburgh Melbourne pp. 165-201.

Blaber, S.J.M., Brewer, D.T. and Salini, J.P. (1995). Fish communities and the nursery role of the shallow inshore waters of a Tropical Bay in the Gulf of Carpentaria, Australia. Estuarine, Coastal and Shelf Science 40: 177-193.

Bryceson, I. (1982). Seasonality of oceanographic conditions and phytoplankton in Dar es Salaam waters. Journal of Science University of Dar es Salaam, 8: 66-76.

Burt, A., Kramer, D.L., Nakatsuru, K. and Spry, C. (1988). The tempo of reproduction in Hyphessobrycon pulchripinnis (Characidae), with a discussion on the biology of 'multiple spawning' in fishes. Environmental Biology of Fishes 22: 15-27.

Cyrus, D.P. and Blaber, S.J.M. (1982). Species identification, distribution and abundance of Gerreidae (Teleostei) Bleeker, 1859 in the estuaries of Natal. South African Journal of Zoology 17: 105-116.

Cyrus, D.P. and Blaber, S.J.M. (1984). The reproductive biology of Gerres in Natal estuaries. Journal of Fish Biology 24: 491-504.

DeMartin, E.E. and Fountain, R.K. (1981). Ovarian cycling and batch fecundity in the Queenfish, 
Seriphus politus: Attributes representative of serial spawning fishes. Fishery Bulletin 79: 547-560.

Etchevers, S.L. (1978). Contribution to the biology of Diapterus rhombeus (Cuvier) (Pisces-Gerreidae), South of Margarita Island, Venezuela. Bulletin of Marine Science 28: 385-389.

Johannes, R.E. (1978). Reproductive strategies of coastal marine fishes in the tropics. Environmental Biology of Fishes 3: 65-84.

Kamukuru, A.T. and Mgaya, Y.D. (2004). Effects of exploitation on reproductive capacity of blacksport snapper, Lutjanus fulviflamma (Pisces: Lutjanidae) in Mafia Island, Tanzania. African Journal of Ecology, 42: 270-280.

Kimaro, M.M. (1986). The composition and abundance of near-surface zooplankton in Tudor Creek, Mombasa, Kenya. M.Sc. thesis, University of Nairobi, 159pp.

Kurup, B.M. and Samuel, C.T. (1991). Spawning biology of Gerres filamentosus Cuvier in the Cochin estuary. Fishery Technology 28: 19-24.

Lambert, T.C. and Ware, D.M. (1984). Reproductive strategies of demersal and pelagic spawning fish. Canadian Journal of Fisheries and Aquatic Sciences 41: 1565-1569.

Lamtane, H.A. (2001). The biology of Gerres oyena (Pisces: Gerreidae) (Forskal, 1775) occurring along the Bagamoyo coast, Tanzania. M.Sc. Thesis, University of Dar es Salaam, 96 pp.

Lowerre-Barbierei, S.K., Chittenden, M.E. Jr. and Barbieri, L.R. (1996). The multiple spawning pattern of weakfish in the Chesapeake Bay and Middle Atlantic Bight. Journal of Fish Biology 48: 1139-1163.

Lowerre-Barbieri, S.K., Lowerre, J.M. and Barbieri, L.R. (1998). Multiple spawning and the dynamics of fish populations: inferences from an individualbased simulation model. Canadian Journal of Fisheries and Aquatic Sciences 55: 2244-2254.
Macer, C.T. (1974). The reproductive biology of the horse mackerel Trachurus trachurus (L.) in the North Sea and English Channel. Journal of Fish Biology 6: 415-438.

Merrett, N.R. (1971). Aspects of the biology of billfish (Istiophoridae) from the equatorial Western Indian Ocean. Journal of Zoology London 163: 351-395.

Ndaro, S.G.M. and Ólafsson, E. (1995). A note on the selection of meiobenthic prey by Gerres oyena in a tropical lagoon in eastern Africa. Ambio 24: 517-519.

Nikolsky, G.V. (1963). The Ecology of Fishes. Academic Press, London. 352pp.

Okera, W. (1974). Morphometric, condition and gonad development of the East African Sardinella gibbosa and S. albella. Journal of Fish Biology 6: $801-812$.

Patnaik, S. (1971). Observations on the fishery and biology of Chilka jagili, Gerres setifer (Hamilton). Journal of Inland Fisheries Society of India 3: 25-43.

Rao, A.V.P. (1970). Observations on some aspects of the biology of Gerres oyena (Forskal) with notes on the fishery of Silver biddies of Pulicat Lake. Journal of Inland Fisheries Society of India 2: 85-100.

Sarre, G.A., Hyndes, G.A. and Potter, I.C. (1997). Habitat, reproductive biology and size composition of Parequula. melbournensis, a gerreid with a temperate distribution. Journal of Fish Biology 50: $341-357$.

Talbot, F.H. (1960). Notes on the biology of the Lutjanidae (Pisces) of the East African coast with special reference to L. bohar (Forskal). Annals South Africa Museum 45: 549-579.

West, G. (1990). Methods of assessing ovarian development in fishes: a review. Australian Journal of Marine and Freshwater Research 41: 199-222. 